\title{
Development of business environment construction in China: a comparative analysis based on typical countries
}

\author{
Yonghui $\mathrm{CAO}^{1, \mathrm{a}}$, He JIANG ${ }^{2, \mathrm{~b} *}$ \\ ${ }^{1}$ Department of Business Administration, Guangzhou College of Technology and Business, Guangzhou, China \\ ${ }^{2}$ Department of Business Administration, Guangzhou College of Technology and Business, Guangzhou, China
}

\begin{abstract}
The World Bank publishes the business environment report every year, ranking the business environment of 190 economies in the world. This paper mainly compares and analyzes the relevant indicators of marketization, legalization and internationalization between China and New Zealand, Singapore, the United States, and points out the existing problems and future improvement measures, so as to provide reference for further improving the competitiveness of business environment in China.
\end{abstract}

\section{Introduction}

According to the world bank's 'Doing Business', through the scores of indicators of each economy, the ranking statistics of business convenience of 190 economies provide an important reference for the horizontal comparison of business environment of each country. Since 2003, the World Bank has published the annual ranking of economies every year. Up to now, the World Bank's measurement indicators of business environment convenience have been stable in ten areas, with 190 economies sampled. For the evaluation of the Chinese business environment, the statistics mainly come from two cities, Shanghai and Beijing, accounting for $55 \%$ and $45 \%$ respectively. Up to now, the World Bank's statistical results show that 186 of 190 economies pay attention to the improvement of business environment, and have made changes in many aspects of business environment in more than ten years, with the number exceeding $3500[1]$.

In October 2019, the World Bank released the annual business environment report. In the ranking of business environment of 190 economies in the world, China's ranking has increased to 31 , which reaching the best in history. It has surpassed the developed country France. It shows that China, as a representative of developing countries, is catching up with the trend of developed economies[1, 2].

Focusing on China's business convenience, China ranks 31st among 190 economies in the world in this year's World Bank report, with a comprehensive score of 77.9, which is the best ranking since China released by World Bank report. The World Bank has a high evaluation of China. Due to the implementation of eight business environment reforms, China has made unremitting efforts for the business environment construction of its market subjects, making China rank more than 10 higher than last year. The report also said that Shanghai, a sample city in China, has better reform experience, which has improved many indicators in China. The World Bank is subdividing Shanghai's reform experience to other countries. In addition, Kazakhstan, Azerbaijan, Myanmar and other 20 countries, most of which are developing countries, have improved their business environment to a large extent. This shows that developing countries pay attention to and make great efforts to improve business environment in recent years.

The World Bank reports that, in the past year, the governments of 115 economies around the world have made 294 reforms in the construction of business environment, which have boosted the business confidence, improved the business convenience of enterprises, and made positive contributions to the economic development of the region and the world.

\section{Comparative analysis of business environment between China and some typical countries}

In World Bank business convenience ranking, the top three are New Zealand, Singapore and Hong Kong. At the same time, the United States also ranks sixth among the top ten countries. In recent years, China has continuously increased its reform efforts and achieved good results. In 2019, China ranks 31st in the world, surpassing France, which ranks 32nd. 
TABLE I. TOP 10 ECONOMIES IN TERMS OF BUSINESS ENVIRONMENT CONVENIENCE IN RECENT THREE YEARS

\begin{tabular}{llll}
\hline Ranking & $\mathbf{2 0 1 7}$ & $\mathbf{2 0 1 8}$ & $\mathbf{2 0 1 9}$ \\
\hline $\mathbf{1}$ & New Zealand & New Zealand & New Zealand \\
$\mathbf{2}$ & Singapore & Singapore & Singapore \\
$\mathbf{3}$ & Denmark & Denmark & Hong Kong \\
& & & Denmark \\
$\mathbf{4}$ & South Korea & Hong Kong & South Korea \\
$\mathbf{5}$ & Hong Kong & South Korea & U.S.A \\
$\mathbf{6}$ & U.S.A & Georgia & Georgia \\
$\mathbf{7}$ & UK & Norway & UK \\
$\mathbf{8}$ & Norway & U.S.A & Norway \\
$\mathbf{9}$ & Georgia & UK & Sweden \\
\hline $\mathbf{1 0}$ & Sweden & Macedonia & \\
\hline
\end{tabular}

According to the World Bank's business environment report, after comparison among the top ten countries in terms of business environment convenience in nearly three years, which is found that New Zealand ranks first and Singapore ranks second in the world[3,4]. This shows that the two countries have made outstanding achievements in the construction of business environment. The United States, the strongest economic, has not fallen in the rankings in the past three years, ranking in the top ten in the world. These countries provide experience and reference for the improvement of Chinese business environment, therefore, this paper selects Singapore, New Zealand and the United States to compare the businesses environmental construction of China. Among these nations, the scores of business environment indicators of Singapore, New Zealand and the United States are shown in the following three tables (table 2-4). Through the comparison of these data, we will make an in-depth analysis from the three aspects of marketization (convenience), legalization and internationalization, so as to find some deficiencies in the construction of business environment in China, and provide reference for the next step to enhance the competitiveness of the Chinese business environment $[5,6,7]$.

TABLE II. SCORES OF VARIOUS INDICATORS OF BUSINESS ENVIRONMENT IN SINGAPORE

\begin{tabular}{|c|c|c|c|c|}
\hline & $\begin{array}{l}\text { DB2020 } \\
\text { ranking }\end{array}$ & $\begin{array}{l}\text { DB2020 } \\
\text { Score }\end{array}$ & $\begin{array}{l}\text { DB2019 } \\
\text { Score }\end{array}$ & $\begin{array}{c}\text { Change } \\
(\%)\end{array}$ \\
\hline total & 2 & 86.2 & 85.8 & 0.4 \\
\hline Starting a Business & 4 & 98.2 & 98.2 & 0 \\
\hline $\begin{array}{l}\text { Dealing with } \\
\text { Construction Permits }\end{array}$ & 5 & 87.9 & 84.7 & 3.2 \\
\hline Getting Electricity & 19 & 91.8 & 91.3 & 0.5 \\
\hline Registering Property & 21 & 83.1 & 83.1 & 0 \\
\hline Getting Credit & 37 & 75.0 & 75.0 & 0 \\
\hline $\begin{array}{l}\text { Protecting Minority } \\
\text { Investors }\end{array}$ & 3 & 86.0 & 86.0 & 0 \\
\hline Paying Taxes & 7 & 91.6 & 91.6 & 0 \\
\hline Trading across Borders & 47 & 89.6 & 89.6 & 0 \\
\hline Enforcing Contracts & 1 & 84.5 & 84.5 & 0 \\
\hline Resolving Insolvency & 27 & 74.3 & 74.3 & 0 \\
\hline
\end{tabular}


TABLE III. SCORES OF BUSINESS ENVIRONMENT INDICATORS IN NEW ZEALAND

\begin{tabular}{|c|c|c|c|c|}
\hline & $\begin{array}{l}\text { DB2020 } \\
\text { ranking }\end{array}$ & $\begin{array}{l}\text { DB2020 } \\
\text { Score }\end{array}$ & $\begin{array}{l}\text { DB2019 } \\
\text { Score }\end{array}$ & $\begin{array}{c}\text { Change } \\
(\%)\end{array}$ \\
\hline total & 1 & 86.8 & 87.0 & -0.2 \\
\hline Starting a Business & 1 & 100 & 100 & 0 \\
\hline $\begin{array}{c}\text { Dealing with Construction } \\
\text { Permits }\end{array}$ & 7 & 86.5 & 86.5 & 0 \\
\hline Getting Electricity & 48 & 84.0 & 84.0 & 0 \\
\hline Registering Property & 2 & 94.6 & 94.6 & 0 \\
\hline Getting Credit & 1 & 100 & 100 & 0 \\
\hline Protecting Minority Investors & 3 & 86.0 & 86.0 & 0 \\
\hline Paying Taxes & 9 & 91.0 & 91.1 & -0.1 \\
\hline Trading across Borders & 63 & 84.6 & 84.6 & 0 \\
\hline Enforcing Contracts & 23 & 71.5 & 71.5 & 0 \\
\hline Resolving Insolvency & 36 & 69.5 & 71.8 & -2.3 \\
\hline
\end{tabular}

Score : Score of business environment convenience Change : Change of business environment convenience score Data from the 2020 Doing Business

TABLE IV. SCORES OF VARIOUS INDICATORS OF BUSINESS ENVIRONMENT IN THE UNITED STATES

\begin{tabular}{|c|c|c|c|c|}
\hline & $\begin{array}{l}\text { DB2020 } \\
\text { ranking }\end{array}$ & $\begin{array}{l}\text { DB2020 } \\
\text { Score }\end{array}$ & $\begin{array}{l}\text { DB2019 } \\
\text { Score }\end{array}$ & $\begin{array}{c}\text { Change } \\
(\%)\end{array}$ \\
\hline total & 6 & 84.0 & 83.6 & 0.4 \\
\hline Starting a Business & 55 & 91.6 & 91.2 & 0.4 \\
\hline $\begin{array}{c}\text { Dealing with Construction } \\
\text { Permits }\end{array}$ & 24 & 80.0 & 79.9 & 0.1 \\
\hline Getting Electricity & 64 & 82.2 & 82.1 & 0.1 \\
\hline Registering Property & 39 & 76.9 & 76.9 & 0 \\
\hline Getting Credit & 4 & 95.0 & 95.0 & 0 \\
\hline Protecting Minority Investors & 36 & 71.6 & 71.6 & 0 \\
\hline Paying Taxes & 25 & 86.8 & 84.1 & 2.7 \\
\hline Trading across Borders & 39 & 92.0 & 92.0 & 0 \\
\hline Enforcing Contracts & 17 & 73.4 & 72.0 & 1.4 \\
\hline Resolving Insolvency & 2 & 90.5 & 90.9 & -0.4 \\
\hline
\end{tabular}

Score : Score of business environment convenience Change : Change of business environment convenience score Data from the 2020 Doing Business 
According to the scores of the first and second level indicators of business environment, we will compare and analyze the business environment convenience between China, New Zealand, Singapore and the United States from the following three aspects.

\subsection{Comparison of Marketization (Convenience) of Business Environment}

The marketization (convenience) evaluation of business environment is mainly reflected by the process, time and cost in the business process, reflecting the level of business convenience of the enterprise main body in the business process. As this aspect is easy to quantify, the data collected is also more detailed, and table 5 reflects the specific situation of China and the other three countries in this aspect. Through comparison, we can find that in terms of handling formalities, China has certain advantages in obtaining electric power, which is also an obvious field of reform in recent years. However, there is still a gap with the other three countries in terms of setting up enterprises and handling construction permits. In terms of property registration procedures, it is in the middle of the four countries. In terms of handling time, China's indicators are generally higher than those of the other three countries. Although China has made positive achievements in handling construction licenses, executing contracts and other aspects, and has been praised by the World Bank, compared with the three countries with advanced international level, China still has a gap. In terms of handling cost, it is at a disadvantage in registering property, paying taxes and handling bankruptcy, and other indicators are at the middle level of four countries. Therefore, in terms of marketization of business environment, although China has made gratifying progress, compared with the international advanced level, we still need to make unremitting efforts to increase reform efforts in terms of procedures, time and cost, especially in terms of the disadvantages mentioned above, we need to make greater efforts to focus on improvement[8,9].

TABLE V. COMPARISON OF BUSINESS ENVIRONMENT INDEX BETWEEN CHINA AND THREE TYPICAL COUNTRIES

\begin{tabular}{|c|c|c|c|c|c|c|}
\hline \multicolumn{3}{|l|}{ index } & China & Singapore & $\begin{array}{l}\text { New } \\
\text { Zealand }\end{array}$ & USA \\
\hline \multirow{4}{*}{ procedures } & \multicolumn{2}{|c|}{ Starting a Business (quantity) } & 4 & 2 & 1 & 6 \\
\hline & \multicolumn{2}{|c|}{$\begin{array}{l}\text { Dealing with Construction } \\
\text { Permits (quantity) }\end{array}$} & 18 & 9 & 11 & 16 \\
\hline & \multicolumn{2}{|c|}{ Getting Electricity (quantity) } & 2 & 4 & 5 & 5 \\
\hline & \multicolumn{2}{|c|}{$\begin{array}{l}\text { Registering Property } \\
\text { (quantity) }\end{array}$} & 4 & 6 & 2 & 4 \\
\hline \multirow{9}{*}{ Time } & \multicolumn{2}{|c|}{ Starting a Business (days) } & 9 & 1.5 & 0.5 & 4 \\
\hline & \multicolumn{2}{|c|}{$\begin{array}{l}\text { Dealing with Construction } \\
\text { Permits (days) }\end{array}$} & 111 & 35.5 & 93 & 81 \\
\hline & \multicolumn{2}{|c|}{ Getting Electricity (days) } & 32 & 26 & 58 & 90 \\
\hline & \multicolumn{2}{|c|}{ Registering Property (days) } & 9 & 4.5 & 3.5 & 15 \\
\hline & \multicolumn{2}{|c|}{ Paying Taxes (Hours / year) } & 138 & 64 & 140 & 175 \\
\hline & \multirow{2}{*}{$\begin{array}{l}\text { Trading } \\
\text { across } \\
\text { Borders }\end{array}$} & $\begin{array}{l}\text { Export time } \\
\text { (Border } \\
\text { compliance, } \\
\text { hours) }\end{array}$ & 21 & 10 & 37 & 2 \\
\hline & & $\begin{array}{l}\text { Import time } \\
\text { (Border } \\
\text { compliance, } \\
\text { hours) }\end{array}$ & 36 & 33 & 25 & 2 \\
\hline & \multicolumn{2}{|c|}{ Enforcing Contracts (days) } & 496 & 164 & 216 & 444 \\
\hline & \multicolumn{2}{|c|}{ Resolving Insolvency (years) } & 1.7 & 0.8 & 1.3 & 1.0 \\
\hline \multirow{5}{*}{ Cost } & \multicolumn{2}{|c|}{$\begin{array}{l}\text { Paid in minimum capital } \\
\text { (per-capita income } \%)\end{array}$} & 0.0 & 0.0 & 0.0 & 0.0 \\
\hline & \multicolumn{2}{|c|}{$\begin{array}{l}\text { Dealing with Construction } \\
\text { Permits } \\
\text { (warehouse value \%) }\end{array}$} & 2.8 & 3.3 & 2.2 & 0.7 \\
\hline & \multicolumn{2}{|c|}{$\begin{array}{l}\text { Getting Credit (per-capita } \\
\text { income \%) }\end{array}$} & 0.0 & 22.0 & 67.9 & 21.7 \\
\hline & \multicolumn{2}{|c|}{$\begin{array}{l}\text { Registering Property (property } \\
\text { value \%) }\end{array}$} & 4.6 & 2.9 & 0.1 & 2.4 \\
\hline & \multicolumn{2}{|c|}{$\begin{array}{l}\text { Total tax rate (business net profit } \\
\text { percentage) }\end{array}$} & 59.2 & 21.0 & 34.6 & 36.6 \\
\hline
\end{tabular}




\begin{tabular}{|l|l|l|l|l|l|l|}
\hline & $\begin{array}{l}\text { Export cost } \\
\text { (border } \\
\text { compliance, } \\
\text { USD) }\end{array}$ & 256 & 335 & 337 & 175 \\
\cline { 2 - 6 } & $\begin{array}{l}\text { Trading cost } \\
\text { across } \\
\text { Borders } \\
\text { compler } \\
\text { USD) }\end{array}$ & 241 & 220 & 367 & 175 \\
\cline { 2 - 6 } & $\begin{array}{l}\text { Enforcing Contracts } \\
\text { (Percentage of subject } \\
\text { amount) }\end{array}$ & 16.5 & 25.8 & 27.2 & 30.5 \\
\cline { 2 - 6 } & $\begin{array}{l}\text { Resolving Insolvency (asset } \\
\text { value \%) }\end{array}$ & 22.0 & 4.0 & 3.5 & 10.0 \\
\hline
\end{tabular}

\subsection{Comparison of the Legalization of Business Environment}

The construction of business environment needs legal protection, and the legal environment also can enhance the investment confidence of enterprises. Therefore, only by comparing the legal system construction of four countries, we can analyze the advantages and disadvantages of business environment construction. From the business environment report of the World Bank, it can be found that New Zealand, Singapore and the United States, which all have relatively complete legal systems, and have certain advantages in the rule of law. From the aspect of intellectual property protection, Singapore has a relatively sound legal system, and has introduced a number of laws and regulations to ensure that enterprises compete in a fair market.

In addition, the United States also attaches great importance to the protection intellectual property rights, and has a relatively sound legislative system. In order to protect the intellectual property rights of enterprises, every state in the United States has formulated corresponding intellectual property laws and regulations according to local conditions. China, as a big country of patent application, has ranked the top three in the world in recent years, with millions of invention patents. Although China has strengthened the protection of intellectual property in recent years, from the actual situation of market feedback, the phenomenon of counterfeiting products and counterfeiting is still prohibited repeatedly, and the phenomenon of bad currency expelling good currency still exists in large numbers, which has brought adverse effects to the business environment of our enterprises. Fortunately, this year's "Regulations on optimizing the business environment" proposed to further strengthen the protection of intellectual property rights, which providing legal protection for the protection of intellectual property rights of enterprises. In addition, in terms of commercial disputes, the United States, New Zealand and Singapore have established relatively perfect judicial systems to solve economic disputes at the lowest cost. At the same time, these countries carry out alternative dispute resolution mechanism, so as to better resolve commercial disputes and conflicts. From the perspective of China's situation, due to the relatively short time of implementing market economy, some commercial dispute settlement systems are not perfect, some laws and regulations lag behind, which greatly reduces the effectiveness of solving commercial disputes. In recent years, with the "deregulation service" reform, China's experience in commercial management is also increasing. Some places keep pace with the times, and have issued a number of relevant policies to protect the interests of enterprises by creating a legal business environment, but the legal degree of business environment still needs to be strengthened.

\subsection{Comparison of Internationalization of Business Environment}

Singapore and the United States attach great importance to the international business environment, and the government plays an important role in cross-border trade. New Zealand has carried out reforms to simplify the import and export approval procedures, encourage domestic enterprises to conduct cross-border operations, improve efficiency and reduce costs. Specifically, Singapore has the most extensive FTA framework in Asia, and it has signed free trade agreements with major economies in the world. At the same time, in order to protect the legitimate rights and interests of domestic enterprises abroad, Singapore has signed more than 30 investment guarantee agreements with other economies. In order to attract foreign enterprises to invest in Singapore, the government have signed agreements with relevant countries to avoid double taxation and created an international business environment with Singapore characteristics. The United States and the European Union launched relevant agreements on international trade and investment partnership in 2013, which committed to building a high level of international cooperation in the world. New Zealand has close economic cooperation with European and American and also is one of the initiators of Trans-Pacific Partnership (TPP).

From the perspective of internationalization of China's business environment, the government is also increasing the formulation and implementation of relevant policies to create a good business atmosphere for foreign enterprises to invest in China and protect the legitimate rights and interests of foreign investors. At the same time, China actively encourages domestic enterprises to go abroad and establish open trade relations with major economies in the world. However, from the perspective of the world economic pattern, in recent years, the western countries dominated by the 
United States have used the so-called international agreements to suppress the international development of Chinese enterprises. The United States and other countries have established a number of major international trade agreements, such as the transatlantic trade and investment partnership agreement, the trans Pacific Partnership Agreement, which exclude China from the agreement and block China's internationalization path through political and economic alliances. In addition, there are differences between some laws and regulations of China and international standards, which leads to many difficulties for Chinese enterprises on the road of internationalization. Therefore, to build an international business environment and cultivate international business talents, which is also the direction that China needs to work harder in the future.

\section{Conclusion}

The World Bank's Research Report on business environment is the result of statistical ranking through ten core areas of business environment and collecting data in a year, which attaches importance to the sense of enterprise's own acquisition, and the collected data are relatively complete. The designed evaluation indicators are comparable, so it has been recognized by most of the world's economies. For the world ranking of China's business environment, the data are mainly collected from the sample cities of Shanghai and Beijing. On the whole, the score of China's business environment is increasing year by year, and the ranking is gradually moving forward. This year, it has reached the best level in history, ranking 31 out of 190 economies in the world, and many indicators have been improved which shows the achievements of China in improving business environment in recent years. However, through the horizontal comparison with other economies, China has seen a large gap, which is also where we need to improve.

Finally, it should be noted that the 'Doing Business' provides a reference for China's institutional innovation and reform. However, we should also recognize the limitations of the report, because the sample cities collected are two cities (Shanghai and Beijing) with strong economic strength, high degree of openness and good business atmosphere. The statistics of these two cities are difficult to summarize and represent the actual situation of business environment in most regions of China. Therefore, based on reference to the report, it is necessary to optimize the China's business environment and improve the competitiveness of enterprises by implementing reform measures adapted to local conditions in combination with the actual situation of China.

\section{Acknowledgment}

This work is financially supported by Guangdong Education Science Planning Project, building an efficient and intelligent supply chain system to promote the highquality economic development of Guangdong-Hong Kong-Macao Greater Bay Area, 2019GXJK072; outstanding scholars of philosophy and Social Sciences in Henan Province higher education in 2018, 2018YXXZ-06; Henan philosophy and Social Sciences Planning Project in 2019, 2019BJJ003; The social development project of Henan provincial key R \& D and promotion project (Science and technology tackling key problems) in 2019, project number: 515; Henan philosophy and Social Sciences Planning Project in 2019, 2019BJJ032; General Topics of Henan Province Educational Science "13th Five-Year Plan" in 2020, 2020YB0146; the key scientific research project of colleges and universities in Henan Province in 2021, 21A620002; Foshan social science planning project in 2020, 2020-QN11; Intellectual property soft science research project of Henan Province in 2021, 20210106014. Thanks for the help.

\section{References}

1. Doing business group of the World Bank. Doing Business 2020. https://chinese.doingbusiness.org/

2. Bao Xiaoye, Liu Jianghui, Huang Guoyan. Reflections on further optimizing the business environment in Shanghai-Based on the world bank business environment assessment report [J]. Shanghai business, 2019 (1): 2

3. Hamilton L, Webster P. The international business environment[M]. Oxford University Press, 2018.

4. Gaganis C, Pasiouras F, Voulgari F. Culture, business environment and SMEs' profitability: Evidence from European Countries[J]. Economic Modelling, 2019, 78: 275-292.

5. Gecevska V, Chiabert P, Anisic Z, et al. Product lifecycle management through innovative and competitive business environment[J]. Journal of Industrial Engineering and Management, 2010, 3(2): 323-336.

6. You K, Dal Bianco S, Lin $\mathrm{Z}$, et al. Bridging technology divide to improve business environment: Insights from African nations[J]. Journal of Business Research, 2019, 97: 268-280.

7. Cepel M, Belas J, Rozsa Z, et al. Selected economic factors of the quality of business environment[J]. J. Int. Stud, 2019, 12: 228-240.

8. Newman C, Rand J, Tarp F, et al. Corporate social responsibility in a competitive business environment $[\mathrm{J}]$. The Journal of Development Studies, 2020: 1-18.

9. Samad K A, Mubarak A S. Being Agile In Dynamic Business Environment[J]. Our Heritage, 2020, 68(1): 3778-3783. 